\title{
CDIO アプローチを活用した工学設計教育
}

\author{
Engineering Design Education through the CDIO Approach
}

\author{
竹 俣 - 也 $^{* 1}$ \\ Kazuya TAKEMATA \\ 南出章 幸※2 \\ Akiyuki MINAMIDE \\ 松 石 正 克 ${ }^{* 1}$ \\ Masakatsu MATSUISHI
}

\begin{abstract}
CDIO is a framework for the engineering education curriculum. It is based on learning the design process through actual system and product development. Students learn to "Conceive-DesignImplement-Operate" within this framework. The CDIO standard needs not to be satisfied by every related subject independently. What is required is just satisfied as a whole. At Kanazawa Institute of Technology (KIT), we have two introductory engineering design courses: Design Project 1 (PD1) and Design Project 2 (PD2). PD1 is given in the first semester of the freshman year and PD2 in the second semester of the sophomore year. Standard PD1 and PD2 courses satisfy the "ConceiveDesign" processes of the CDIO approach. The authors succeeded in expanding the processes of CDIO in PD2 course. This paper describes the details of engineering design education based upon the CDIO framework.
\end{abstract}

Keywords : Engineering Design Education, CDIO, Design Thinking

キーワード：工学設計教育, CDIO, デザイン思考

\section{1.はじめに}

CDIO は次世代のエンジニアを育成するための工学 教育カリキュラムの枠組みであり, 現実のシステム や製品開発における設計過程を背景にした教育プロ グラムのガイドラインである ${ }^{1)}{ }^{21}$. 学生はこの枠組 みで学習することでCDIOが定義する“考え出す力 (Conceive)”, “設計する力 (Design)”，“実行する力 (Implement)”, “運営する力 (Operation)”を身に付 けることができる。このCDIOのガイドラインは 2000 年にCDIO Initiativeと呼ばれる工学教育改革を目的と する国際プロジェクトによって作成され，2004年にそ の枠組みを完成させている. 現在，30か国以上から約 80の高等教育機関が加盟し, 工学教育の世界標準にな りつつある. 我が国では金沢工業高等専門学校が 2010 年12月にCDIO加盟校になったのが最初である. 金沢 工業大学 (以下, 本学) は2011年 6 月に加盟している.

本学の工学設計教育カリキュラムの基幹科目として プロジェクトデザイン I， プロジェクトデザイン II , プロジェクトデザイン IIIがある. 本学は 2 学期制であ り, プロジェクトデザイン I は学部 1 年次前学期に, プロジェクトデザイン II は 2 年次後学期に，そしてプ ロジェクトデザイン III（卒業研究に相当）は 4 年次に 履修する，学年に応じてこれらの基幹科目に関連する

2011 年 7 月 15 日受付

※ 1 金沢工業大学基礎教育部

※ 2 金沢工業高等専門学校電気電子工学科
科目があり，全体としてCDIOの枠組みを満足するカ リキュラムとして成り立っている。

本学が工学設計教育を導入したのは1996年からで問 題発見, 課題探求型教育による能力の総合化を目的と している ${ }^{3), 4)}$. 当時, 科目名は工学設計 I, 工学設計 II, 工学設計正であった. 2008年, 工学系 3 学部から 「バイオ・化学部」を加えた 4 学部体制になったのを 機会に工学設計という名称をプロジェクトデザインに 変更している，筆者はプロジェクトデザイン I および プロジェクトデザイン II の専任教員として，これまで 教材開発掞よび教育実践を担当してきた。両科目では 学生が学期中にチームを組んでプロジェクト活動を推 進し, 問題発見・解決型の学習を行う。このような形 式の学習がPBL (Project-Based Learning) である ${ }^{5)}$. 学生のプロジェクトは, 実社会における身近な問題を 対象に, 現在持っている知識に加えさらに必要な情報 を集め, チーム活動を通してその問題の解決策を提示 する ${ }^{6)-12)}$. 両科目を履修する学生数は各々約 1,600 名, 学期中に推進されるプロジェクトは各々約300件に及 び, 他校に例を見ない.

本論文では, CDIOコンセプトに基づく工学設計過 程という視点から本学のプロジェクトデザイン I およ びプロジェクトデザイン II で実施されている学生のプ ロジェクト活動について述べる. 本学の学生はプロジ エクトデザイン I およびプロジェクトデザイン II の履 修を終えた段階で，CDIOで身に付けるべき力として 示されている“考え出す力ー設計する力（以下, CD と 
する)”の部分までを満足している ${ }^{13)}$ 。ここではそれを “I：実行する力”，さらに“D：運営する力”の部分 まで発展させるための教育実践について検討する.

\section{2. 工学設計過程と CDIO との関係}

図 1 は本学の工学設計過程と CDIO との関係を示し たものである。横欄が本学の工学設計過程, 縦欄が CDIOの定義している学習者が身に付けるべき能力で ある。

図 1 の横欄に示されている工学設計過程について述 ベる.プロジェクトデザイン I 抢よびプロジェクトデ ザイン II は 1 クラス 40 名前後で構成される．5名から 7 名で 1 チームを作る，学生チームはプロジェクトの 活動として次の 5 つのステージに取り組む。本学では この 5 つのステージを工学設計過程と定義している.

(1)問題の発見ステージ : プロジェクト活動として值 する問題を見出す.

(2)問題の明確化ステージ：ニーズ調査などを通して その問題の本質を見極め, その問題に関わる人(工 ーザー）のニーズを明らかにする.

(3)アイデアの創出ステージ : ブレーンストーミング などの発想法を使って多くのアイデアを提示して いく.

(4)アイデアの評価・選定ステージ : 実現の可能性を 検討するための評価基準を設け, メンバー内の合 意形成に基づき最も実現性の高いアイデアを解決 策として選定する。

(5)アイデアの具体化ステージ : 解決策の実現可能性 を検討し（アイデアをより具体的なものにし），そ の結果をポスター発表掞よび報告書として提示す る.

プロジェクトデザイン I のプロジェクトでは(1)から (3)の, プロジェクトデザイン II のプロジェクトでは(3) から(5)のステージを中心に活動する. プロジェクトデ ザイン II ではプロジェクトデザイン I の報告書から興 味深いプロジェクトを選択し，それを引き継ぐ形式を 取っている，そのため，プロジェクトで取り組むステ ージの一部分が重複している. プロジェクトデザイン

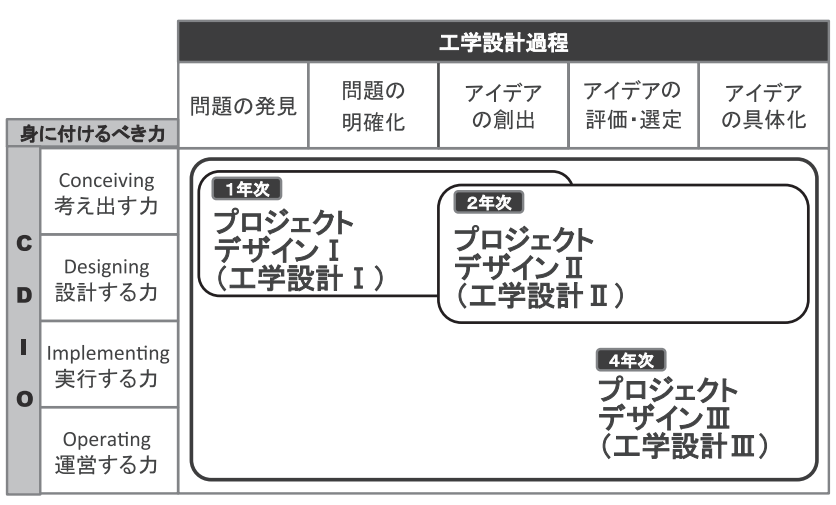

図 1 金沢工業大学・ 工学設計過程とCDIO の関係
II の最初の活動は, プロジェクトデザイン I の成果の 見直しである。ただし，一部のチームはプロジェクト デザイン IIにおいて新規の課題（例えば，自治体（石 川県野々市市）から提示された課題）に取り組み， 久 テージ 2 から開始する場合もある. 本学の 1 学期は 16 週である.プロジェクトデザイン I およびプロジェク トデザイン II はそれぞれ 2 単位, 1 週あたり 45 分 2 コ マで，プロジェクトの実施期間は15週である．16週目 を自己点検週として授業アンケートなどを実施してい る.

\section{CDIOの “CD”から “CDI”・ “CDIO”への発展}

$\mathrm{CDIO}$ の視点から本学のプロジェクトデザイン I 扮 よびプロジェクトデザイン II に扔ける工学設計過程を 見ると「C：考え出す力」が工学設計過程に扔ける問 題の発見ステージおよび問題の明確化ステージに該当 する.「D：設計する力」が工学設計過程におけるア イデアの創出ステージ，アイデアの評価・選定ステー ジ，アイデアの具体化ステージに該当する. CDIOの “I”や“O”の部分まで発展させる場合, プロジェク 卜活動の中で“もの（製品やシステム）”を作り上げ, それを運用しなければならない.“もの”とは, 解決策 の程度が完成形に近い「もの, こと」であり, それが 実利用に耐えうるのであればよい，そのためにはアイ デアの具体化ステージに扔けるプロトタイプづくりを 充実させることが必要である．ここでのプロトタイプ とは問題点を洗い出すために試作した「もの，こと」 だけでなく，それを利用することでユーザーの生活が どのように変化するかを示した書類等も含むものとす る.

図 2 にコップの設計を例に, 筆者のこれまでの経験 からプロジェクトデザイン II の学生が取り組むことが 可能なプロトタイプの表現方法の一部を示す. 図中の 表現は我々が授業において学生に推奨しているコミュ ニケーション・ドローイングの手法によるものであ $b^{14)}$. 試作したコップ(a)の使用感を調べる $(\mathrm{b})$, その コップを利用することでユーザーの生活がどのように 変化するかを検討する (c), それを使っている人の様 子をビデオ撮りして使用状況を検討する (d), 飲み物 を入れたコップの表面温度などの物理量を計測し, 改 善に役立てる (e), 得られたデー夕を統合して解決策 をポスターで紹介する $(\mathrm{f})$ ，などである，プロトタイ プづくりは手を使ったアイデア発想法と捉えることが できる．作ったものを人に見せるというよりも，作る その過程でアイデアをより具体的なものにしていくと ころに意義がある ${ }^{15)}$.

図 3 は工学設計過程に扔ける学生のプロジェクト活 動の流れを示したもので, 常にフィードバックを伴う 設計活動が要求される。ユーザーのニーズを満足して いないと思われるならば再度ユーザーの特性を洞察し 


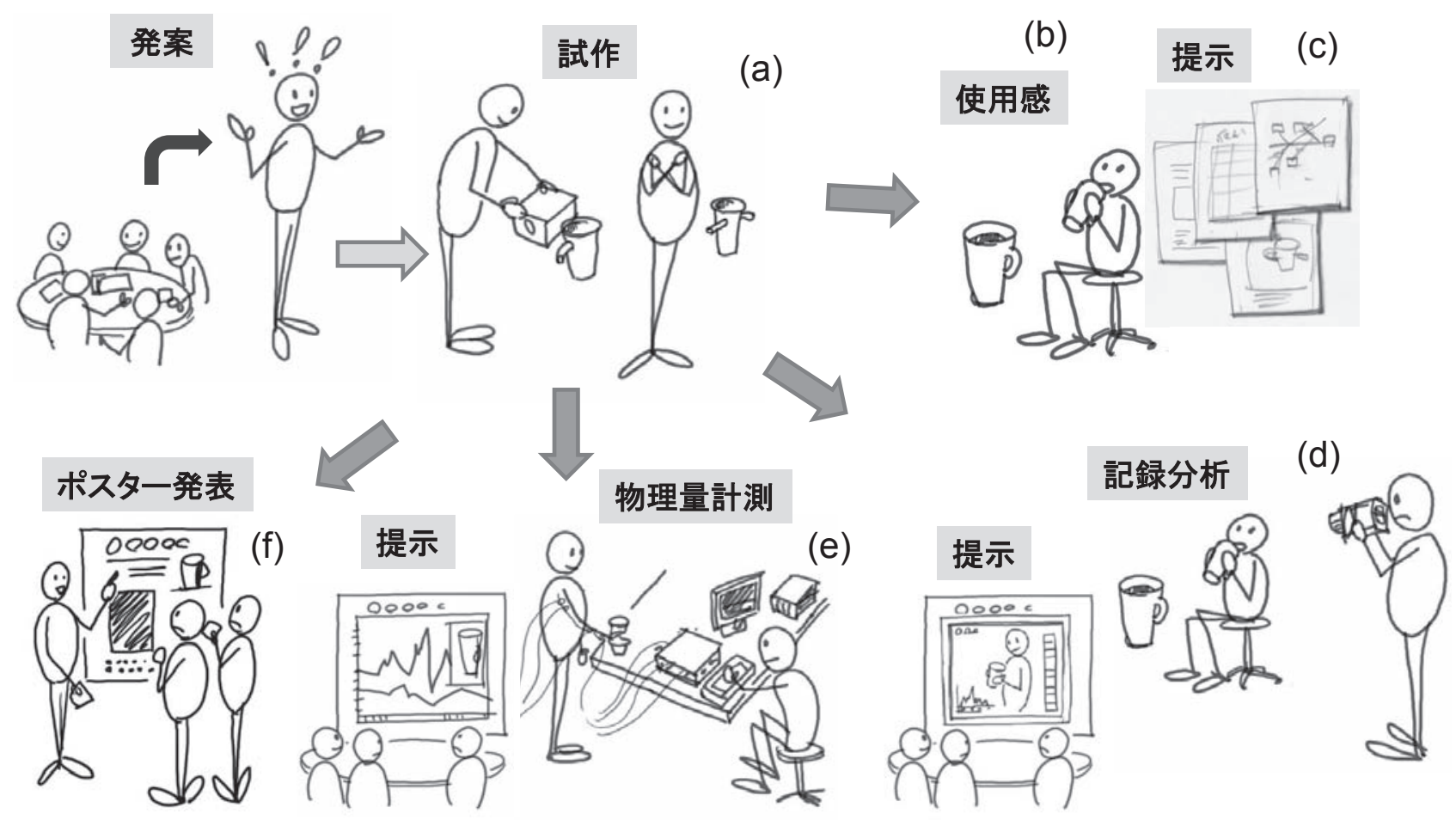

図 2 多様なプロトタイプの表現（コップを例にした場合）

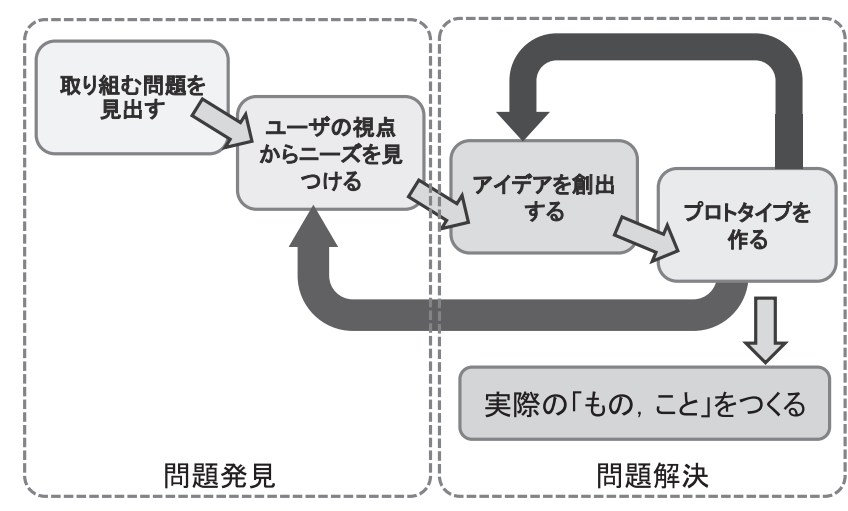

図 3 プロジェクト活動の流れ

たり，ニーズを満足していても解決策に改善の余地が あるならばアイデアを練り直せばよい。このフィード バックが学生の問題発見-問題解決の能力をバランス よく育成することにつながる.

図 4 は2009年のプロジェクトデザイン I の中で学生 から提出されたプロトタイプで，段ボールで製作した ゴミばさみである。プロジェクトデザイン I ではアイ デアを図で示す程度でよいが, このチームはアイデア の妥当性を明らかにするためにこのゴミばさみを試作 している. プロジェクトデザイン I としては十分すぎ る成果物である，学生がプロトタイプブくりを通して ユーザーの立場からアイデアを再考することは，問題 解決に偏重しすぎる傾向にあるプロジェクト活動を早 期に修正し，バランスの取れた問題発見一問題解決の 学習につながることを, この事例は示唆している.

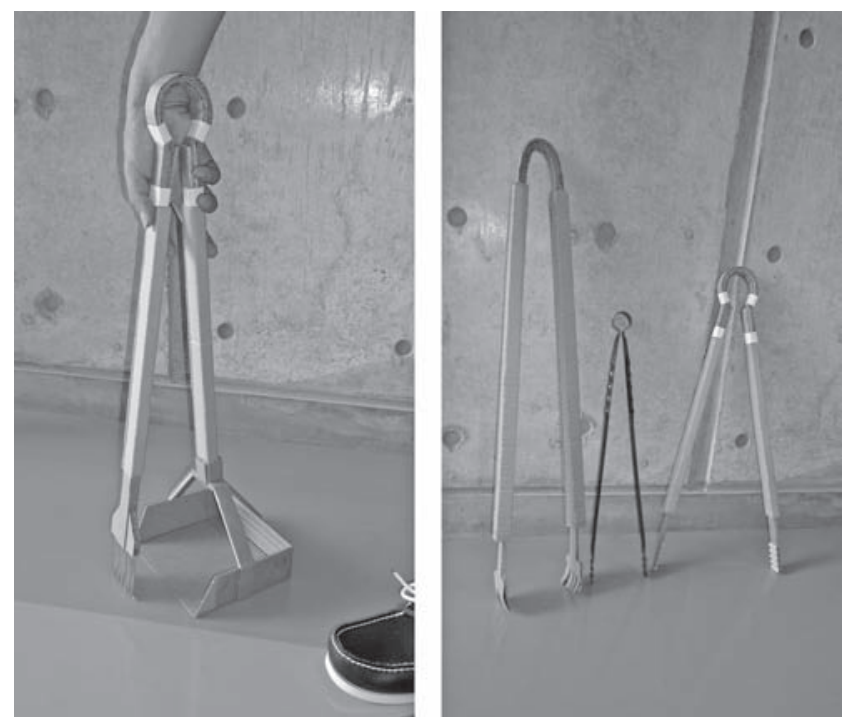

図 4 掃除が楽しくなるゴミばさみ（2009年前学期）

\section{4. 教育実践例とその評価}

筆者のこれまでのプロジェクトデザイン II の教育実 践の中で, 学生チームの到達度によってはプロジェク ト活動をCDIOの “CD” の部分から “CDI”, さらに “CDIO”の部分まで発展させた事例について述べる.

\section{1 教育実践}

事例 $1 ：$ 環境教育プログラムの作成と授業実践 図 5 は2007年度の工学設計 II （現プロジェクトデザ イン II）において学生チームが小学生を対象とした環 境教育プログラムを開発し, 近隣の小学校（金沢市立 額小学校）で教育実践したときの様子である.このチ 一ムはアイデアの具体化ステージに扔いて, 小学校と 交渉して研究授業を実現させている. 訪問先の小学 4 


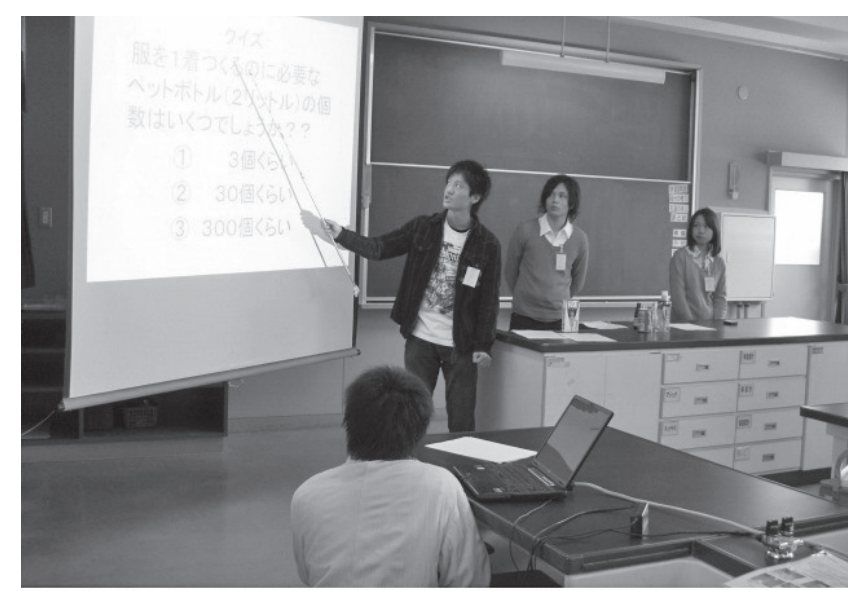

$\mathrm{a} ： 4$ 年生の各クラスで地球環境について授業

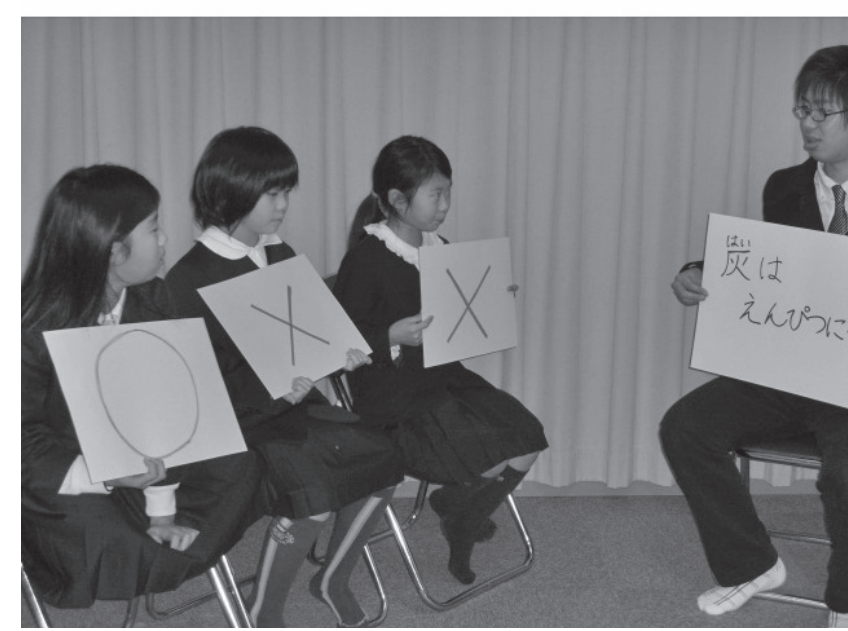

b : 地球環境を題材にした校内放送に出演

図 5 環境教育プログラムを開発し，小学校で実践 （金沢市立額小学校，2008年 1 月25日）

年生全クラス（3クラス）を対象に 1 クラスずつ授業 を行い，さらに給食時間における校内放送に出演した り，校内ポスターを提示したりしてチームが提案する 環境教育プログラムを実施した。この学生らは授業計 画を立て，小学校との交渉を終え，実際に授業を展開 しているのでCDIOの “CDIO”の部分まで実現してい る。この教育プログラムを他校においても実践し改善 していくことができれば，より完成形に近い教育プロ グラムに仕上げることができる.

事例 $2 ：$ コュニティーバス運行支援システムの 開発とインターンシップ

図 6 は2008年の工学設計 II （現プロジェクトデザイ ン II ）の学生チームが野々市町内（現野々市市内）を 運行するコミュニティーバスの時刻表システムを開発 した事例である．工学設計 II では2003年より野々市町 から課題の提供を受けている ${ }^{16)}$. 2008年よりさらにこ の取り組みを発展させ，提供されたテーマに取り組ん だチームは学期末, 役場庁舎にて成果報告会を実施し ている ${ }^{17)}$ ．ただし，発表時間と会場の制約のため，発 表チーム数は該当チーム数の $60 \%$ ，約 20 チームに限定 している。図中の学生は，その報告会で職員の興味を

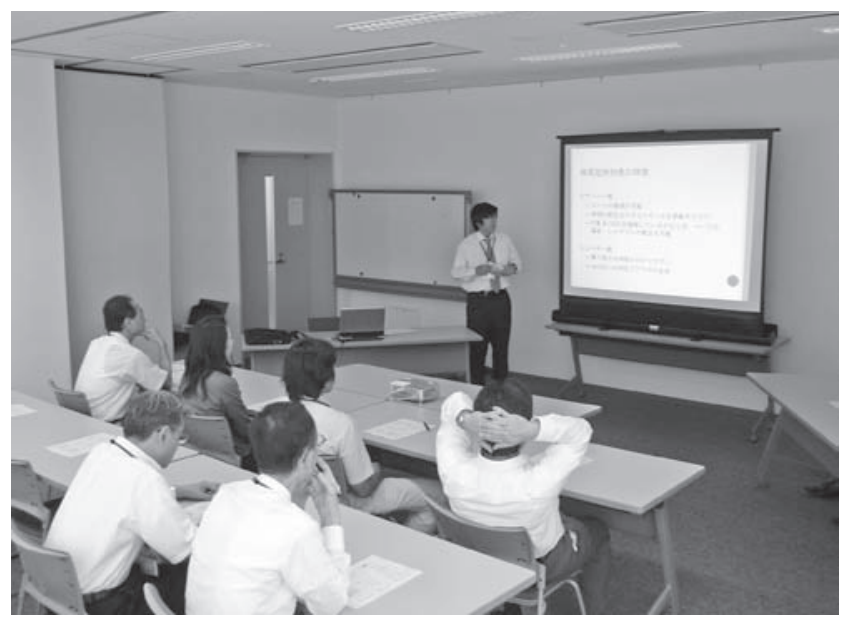

図 6 インターンシップ成果報告会において開発システム を説明する本学の学生

（野々市町役場庁舎，2009年 9 月18日）

引く発表を行い，翌年度の夏期休暇期間中に役場で実 施されたインターンシップ研修に参加することができ た。インターンシップ研修を利用し，役場業務を体験 しながら自らが提案したシステムを実利用可能なもの にまで発展させた。図はインターンシップ最終日に役 場庁舎内で実施された成果報告会の様子である。この 学生はコミュニティーバス運行支援システムを町民へ のサービスとして運営させるところまで実施できたの で, CDIOの “CDI”の部分, さらにCDIOのすべてま でを実現している。この学生が 3 年次に進級し, 専門 科目の学習で得た知識もこのシステム開発に寄与して いることも留意すべきである.

事例 3 : 手作り絵本による読み聞かせ支援

CDIO のすべての過程を満足させる教育実践を行う ためには, 学外の方々にプロジェクトの成果物を評価 してもらうシステムの構築が必要である. 完成形に近 い「もの,こと」を作り上げたらそれを実行する場の確 保が重要となる。図 7 は2010年度のプロジェクトデザ イン II で, 自作の絵本を園児たちに読み聞かせるプロ ジェクト活動である. アイデアの具体化のステージに おいて自らが制作した絵本の有効性を検証するため, 野々市町立押野保育園を訪問し, 園児を対象に本の読 み聞かせを実施した事例である。

プロジェクトの概略は以下の通りである. 先ず, 学 生らは問題の発見ステージにおいて, OECD生徒の学 習到達度調査（PISA2006およびPISA2009）から子供 の読書活動の推進の必要性を知り ${ }^{18)}$, プロジェクトテ ーマとして“子供の読解力を向上させる”ことを選定 した. 問題の明確化ステージでは野々市町立図書館を 訪問し, 野々市町が実施している野々市町子ども読書 活動推進計画の下で子供がどのような図書と向き合っ ているかを調査した，次に自作の絵本にはどのような ストーリーや機能があるべきかについてアイデアを出 し合い,アイデアの具体化ステージで読み聞かせに使 


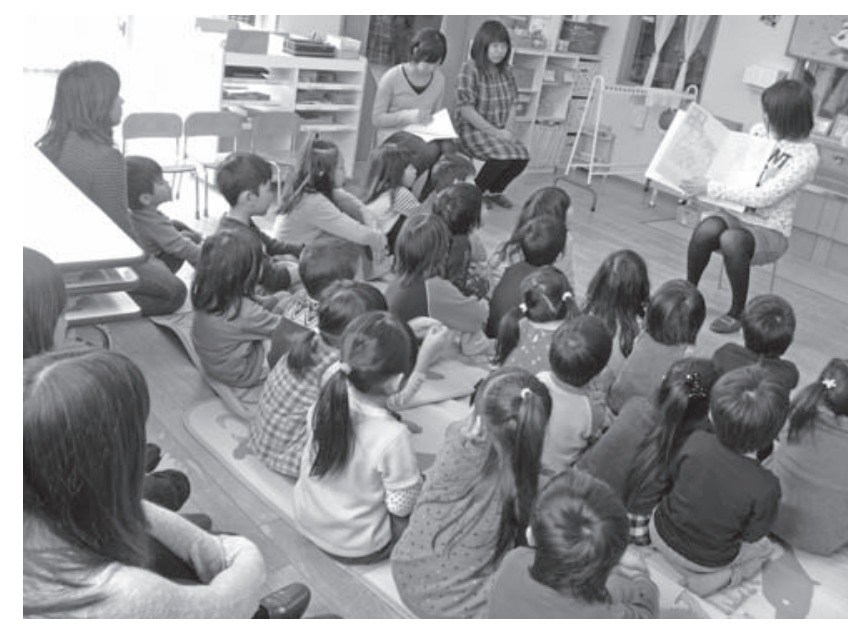

図 7 絵本を製作し, 保育園で実践

（野々市町立押野保育園，2011年 1 月22日）

用する絵本を試作した，試作した絵本の有効性を検証 するために保育園の協力を得て，実際に園児に対して 読み聞かせを実施した。読み聞かせを終えた後, 関係 者から感想を聞いた．園児らの反応はよかったが，保 育士の方々からは「園児は目新しいのでよく見ていた が, 話に起承転結を取り入れるべき」など, 厳しい評価 を受けた。この保育園での活動は学生らにとってアイ デアの外部評価の場であり, 厳しい評価は次のプロジ エクト活動につながる．プロジェクトデザイン II の中 で絵本を製作しただけではCDIOの “CD”の部分（本 学プロジェクトデザイン II の標準レベル)に留まるが, 保育園を訪問し試作した絵本を第 3 者から評価しても うことで，完成形に近い「もの，こと」を作り上げる ことができている，また，専門家（保育士）から評価 を得るといった学外評価システムも機能している。こ のような評価システムがあれば, 学生のプロジェクト 活動はCDIOの “CD”の部分から“CDI”の部分まで 発展させることができる，さらに，本を読み聞かせる 場を運営しているので, 学生らは“CDIO”まで実現し ている。.さらに, 絵本と読み聞かせの場の運営を他の 保育園で実施し改善していくことができれば，より完 成形に近い絵本の読み聞かせの場の構築につながる.

\section{2 工学設計過程の評価}

学生のプロジェクト活動を CDIOの “CD”の部分か ら“CDI”, さらに“CDIO”の部分まで発展させるに は, 学生の行動力に加え, 教員に対して教室全体に対 する運営力や各チームが遂行するプロジェクトに対す る指導力が求められる.さらに学生が取り組むテーマ に対して協力的なユーザーの存在が必要であり, 教員 にはそのユーザーと学生プロジェクトをつなげていく 企画・行動力が必要となる. 上述の 3 つの事例はユー ザーに対するニーズを的確に捉えていたからこそ，プ ロジェクトをCDIOの “CDI”さらに“CDIO”まで発 展できた。どのチームもより良い解決策を提示してい くためにプロトタイプづくりを通してアイデアを再考
表 1 事例で挙げたプロジェクトの評価

\begin{tabular}{|c|c|c|c|c|c|c|}
\hline & \multirow{2}{*}{\multicolumn{2}{|c|}{ 学生プロジェクトの評価指標 }} & \multirow{3}{*}{$\begin{array}{c}\text { 事 } \\
\text { 例 } \\
1 \\
0 \\
\end{array}$} & & \multirow{3}{*}{$\begin{array}{c}\text { 事 } \\
\text { 例 } \\
3 \\
\end{array}$} \\
\hline & & & & & \multirow{2}{*}{\begin{tabular}{|c|}
$\begin{array}{c}\text { 事 } \\
\text { 例 } \\
2\end{array}$ \\
0 \\
\end{tabular}} & \\
\hline \multirow{3}{*}{ C } & \multirow{3}{*}{ 考え出せる } & 1 & 問題の発見 & & & \\
\hline & & 2 & 問題の明確化（ニーズ調査） & O & O & O \\
\hline & & 3 & 設計仕様の作成 & $\bigcirc$ & O & O \\
\hline \multirow{3}{*}{ D } & \multirow{3}{*}{ 設計できる } & 4 & アアイデアの創出, 評価, 選定 & $\bigcirc$ & $\bigcirc$ & $\bigcirc$ \\
\hline & & 5 & アイデアの具体化 & O & 0 & O \\
\hline & & 6 & 企画書 - 設計書の作成 & O & 0 & $\bigcirc$ \\
\hline \multirow{3}{*}{ I } & \multirow{3}{*}{ 実行できる } & 7 & $\begin{array}{l}\text { 交渉, スケジュールの立案, } \\
\text { 進渉管理 }\end{array}$ & $\bigcirc$ & $\bigcirc$ & O \\
\hline & & 8 & アイデアの実装 & O & 0 & O \\
\hline & & 9 & $\begin{array}{l}\text { 制作物の動作確認とその自己 } \\
\text { 評価 }\end{array}$ & $\bigcirc$ & 0 & O \\
\hline \multirow{3}{*}{$\mathrm{O}$} & \multirow{3}{*}{ 運営できる } & 10 & 成果の発信 & $\bigcirc$ & $\bigcirc$ & O \\
\hline & & 11 & 制作物の外部評価 & $\bigcirc$ & 0 & O \\
\hline & & 12 & $\begin{array}{l}\text { 制作物に対する改善案の提案 } \\
\text { と改善 }\end{array}$ & & $\bigcirc$ & \\
\hline
\end{tabular}

している点も共通している.

表 1 にCDIOアプローチを活用した工学設計過程の 評価指標を定義し, 上述の学生のプロジェクト活動を 評価した. どの事例も外部評価を得ている点はよいが, 15週というプロジェクト活動の期間では “運営できる (Operation)”を十分に達成することは難しく, 事例 2 で示したようにインターンシップと連携させるなどの 方策が必要である。

\section{5. まとめ}

本論文では筆者がこれまで担当してきた工学設計科 目であるプロジェクトデザイン I およびプロジェクト デザイン II の実践例を挙げて, 本学の工学設計過程と CDIO との関連を述べた. 工学設計過程に従ってプロ ジェクトを進める両科目は, すでにCDIOの“CD”の 部分までを満足していることを述べた。 また, 場合に よっては “CDI”の部分まで, もしくはCDIOすべて まで実践できることも述べた，CDIOは工学教育カリ キュラムの枠組みであるから，これを一つの科目で満 足する必要はない，学生に提供する科目群が協調し合 い,カリキュラム全体としてCDIO 基準を満足すれば よい. しかしながら基幹科目であるプロジェクトデザ インI およびプロジェクトデザイン II をより充実した 内容にすることは本学の工学教育の底上げになる.

本学の工学設計過程は前半のステージで問題発見の 能力を, 後半のステージで問題解決の能力を育成でき るようになっている. しかしながら，ユーザーのニー ズを十分に把握することなくプロジェクトを進めると アイデア創出からアイデアの具体化の段階において戸 惑うことがある。これを防ぐためにもアイデアの具体 化ステージでプロトタイプを作りながら, 提示しょう としている「もの, こと」がユーザーのニーズを満足 
しているかを再考することは, バランスの取れた問題 発見一問題解決型の教育につながる。 また, 解決策の 検証を学外で実施すれば，それが第 3 者からの評価と なる，そこでの意見を取り入れることで，より完成形 に近い「もの，こと」を作り上げることができる，こ れにより工学設計過程に従って学生が推進するプロジ エクトをCDIOの“CDI”または“CDIO”へと発展さ せることができる，そのためにもこれまで以上に地域 との連携を密にしていくことが重要である ${ }^{19), 20)}$.

21世紀のものづくりでは，ものづくりにデザイン思 考の方法論を適用し,「もの, こと」が使用者にとって 新たな付加価值を生み出すことが必要となってきてい る21). また，持続可能な社会を構築するためにものづ くりが自然環境にも調和しなければならない22)。その ためにも学生が知識を応用して新しい価值を生み出す ための能力を育成するには, 工学設計過程の各ステー ジに抒いて解決策が人とどのように関わるかを，常に 学生らに意識させてプロジェクトを進めさせることが 必要である。それにより, 学生の問題発見能力および 問題解決能力の育成をバランスよく実施することがで きる。

\section{謝 辞}

本論文をまとめるにあたって助言をいただいた金沢 工業高等専門学校・山田弘文校長に媣く感謝いたしま す。また, 本論文におけるイラスト作成䇽よび筆者(竹 俣）のコミュニケーション・ドローイングスキルの向 上に対して本学基礎教育部・中村純生准教授にご指導 いただきこここ感謝いたします。2001年 4 月から 2010年 3 月までの間，筆者と共にプロジェクトデザイ ン I およびプロジェクトデザイン II を担当された古川 哲郎氏に数多くの助言をいただきました。ここに深く 感謝いたします，最後に，筆者の教育実践に対して助 言をくださる本学基礎教育部・松本重男教授, 山川武 人教授, 磯崎俊明教授に感謝いたします。

\section{参 考 文 献}

1 ) Crawley, E.F., Malmqvist, J., Ostlund, S., Brodeur, D.R. : Rethinking Engineering Education, The Cdio approach, Springer-Verlag, 2007

2 ) Worldwide CDIO Initiative : CDIO Collaborators, http://www.cdio.org/cdio-collaborators, 参照日: 2012-3-7

3）松本重雄, 前川晴義, 久保猛志, 松石正克 : 金沢工 業大学の工学設計 I ・ II について, 設計工学, 368, pp. $25-31,2001$

4) 松本重男, 松石正克, 竹俣一也, 古川哲郎, 久保猛 志：学生がチームで設計プロセスに取組む科目の 教育成果, 工学教育, $50-3$, pp.76-82, 2002

5 ）上杉賢士:PBL情報化社会の新たな学習法, 教育学
術新聞, no.2362, 2009

6 ）竹俣一也, 松石正克, 山本敏幸, 古川哲郎, 松本重 男：工学設計科目に扔ける $\mathrm{e}$-Learningシステム活 用の試み, 工学教育, $52-5$, pp. $42-46,2004$

7 ) 松石正克, 竹俣一也, 古川哲郎, Sanders, W., Loo, C. N., : 日本, 米国およびシンガポールの高等教育 機関における工学設計教育の国際交流, 工学教育, 54-4, pp.11-15, 2006

8 ) 古川哲郎, 松石正克, 松本重男, 竹俣一也, 山川武 人: チーム活動能力の育成と評価, 工学教育, $55-$ 4, pp. $75-80,2007$

9 ) 山川武人, 松石正克, 松本重男, 竹俣一也, 古川哲 郎： $1 \cdot 2$ 年次に打ける工学設計科目 - 授業改善 活動と教育効果 -, 工学教育研究, 13, pp.69-82, 2007

10）山川武人, 松石正克, 松本重男, 竹俣一也, 古川哲 郎:工学設計科目における $1 \cdot 2$ 年次生の技術者倫 理教育, 工学教育研究, 14, pp.81-95, 2008

11) Furukawa, T., Matusishi, M., Matumoto, S., Takemata, K., Yamakawa, T., Rynearson, L. : Ways of using and characteristics of two team contribution peer-evaluation methods, INNOVATION 2010 : World Innovations in Engineering Education and Research, pp.21-31, 2010

12）山川武人, 松石正克, 松本重男, 竹俣一也, 磯崎俊 明: 社会人基礎力育成・評価プログラムへの取り 組みと成果, 平成 22 年度 工学・ 工業教育研究講 演会講演論文集, pp. $546-547,2010$

13) Pee, S. H., Leong, H.: Implementing project based learning using CDIO concepts, 1st Annual CDIO Conference, 2005, http : //02e6f35.netsolvps.com/ files/document/file/CDIO_paper12.pdf, 参照日： 2011-4-27

14）中村純生：アイデア・ドローイング 第 2 版ーコミ ユニケーションッールとして - , 共立出版, 2009

15) Department of Educational Development, Singapore Polytechnic:Design Thinking, http:// spdesignthinking.sg/sitemap.html, 参照日:20114-27

16）竹俣一也, 松石正克, 松本重男, 古川哲郎, 山川武 人：地域社会と連携した創造性工学教育, 工学教 育, $54-2$, pp. $81-86,2006$

17）竹俣一也, 松石正克, 松本重男, 古川哲郎, 山川武 人：工学設計教育科目に扔ける地域との連携事例 (4), 平成 21 年度 工学 - 工業教育研究講演会講演 論文集, pp.84-85, 2009

18）国立教育政策研究所：OECD生徒の学習到達度調 查(PISA), http : //www.nier.go.jp/kokusai/pisa/ index.html, 参照日 : 2011-4-27

19) Takemata, K., Minamide, A., Furukawa, T., : 
Local support for lifelong learning with science experiment courses(2), Proceedings of the International Conference on Engineering Education (ICEE2009), 2009

20) Takemata, K., Nakamura, S., Minamide, A., : Design of a lifelong learning program with regional collaboration, Internship for high school students, INNOVATION 2011 : World Innovations in Engineering Education and Research, pp.3-11, 2011

21) Brown, T. : Change by Design, How Design Thinking Transforms Organizations and Inspires Innovation, HarperBusiness, 2009.

22）日本学術会議機械工学委員会生産科学分科会：21
世紀ものづくり科学のあり方について 2008年 9 月18日, http : //www.scj.go.jp/ja/info/kohyo/ pdf/kohyo-20-h64-2.pdf, 参照日：2011-4-27

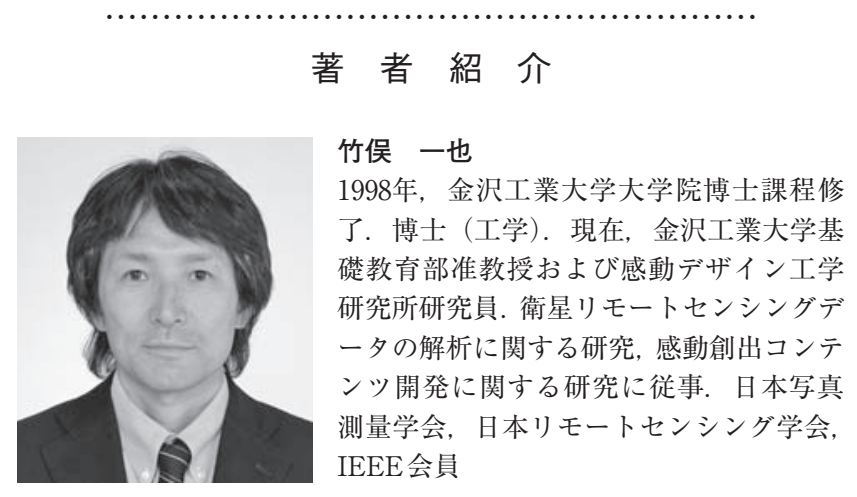

